\title{
Cryotherapy for Lichen Striatus in an Adult - a Case Report
}

Slobodan STOJANOVIĆ ${ }^{1,2}$, Marina JOVANOVIĆ ${ }^{1,2}$, Nada Vučković ${ }^{1,3}$

${ }^{1}$ Faculty of Medicine, University of Novi Sad, Republic of Serbia

${ }^{2}$ Clinic of Dermatovenereology Diseases, Clinical Center of Vojvodina, Novi Sad,

Republic of Serbia

${ }^{3}$ Pathology and Histology Center, Clinical Center of Vojvodina, Novi Sad, Republic of Serbia

*Correspondence: Slobodan STOJANOVIĆ, e-mail: slobodanstojanovicns@sbb.rs

UDC 616.51-002-079.4

UDC 616.51-002:615.832.9

\section{DE GRUYTER OPEN}

\begin{abstract}
Lichen striatus (linear lichenoid dermatosis) is an uncommon, self-limited, inflammatory, linear skin condition of unknown origin. The causes of linear distribution are unknown, though the pattern of lichen striatus (LS) mostly follows the lines of Blaschko (BL). The condition most commonly occurs in children between 5 and 15 years of age, usually after the first year of life.

We report a 27-year-old, otherwise healthy flight attendant with LS whose diagnosis was based on: the history of sudden appearance and rapid linear spread of lesions; clinical presentation of small pink, coalescing scaly papules without umbilication or Wickham's striae, linear distribution following one BL down a lower limb to the ankle, with a band broadening into plaque on the left buttock; histology showed some hyperkeratosis, lichenoid dermatitis similar to lichen planus, but with the presence of inflammatory infiltrate in the papillary dermis and also deeper in the perifollicular region. The inflammatory infiltrate consisted mainly of limphocytes, with some melanophages and histiocytes.

There is no standard treatment for LS, and it is given for cosmetic or psychological reasons only, as we have done in our patient due to slight pruritus and occupational reasons. With regard to her occupational demands, in order to achieve satisfying results, she was successfully treated with cryotherapy, which she tolerated well, without any side effects. Cryotherapy was performed twice, with a two-week interval. Full resolution was achieved twelve weeks after cryotherapy.

In conclusion, we present an adult female who developed lichen striatus suddenly three months after delivery and was successfully treated with cryotherapy.
\end{abstract}

\section{Key words}

Lichen Sclerosus et Atrophicus; Lichenoid Eruptions; Adult; Cryotherapy; Treatment Outcome; Case Reports

$\mathrm{L}$ ichen striatus (linear lichenoid dermatosis) is an uncommon self-limited, inflammatory, linear dermatitis of unknown origin. The factors causing linear distribution are unknown, though the pattern of lichen striatus (LS) follows the lines of Blaschko (1, $2,3)$. The condition most commonly affects children between 5 and 15 years of age, usually after the first year of life. A female to male predominance of $2: 1$ has been reported $(1,2,4)$. Occasionally, LS is seen in adults as a linearly distributed array of closely adjacent small flesh-colored, erythematous to pinkish papules without umbilication or Wickham's striae, with little or no scales $(1,4)$. LS is characterized by rapid development: discrete at first, small papules rapidly coalesce, soon forming a dull-red, slightly scaly, often irregular linear band, usually $2 \mathrm{~mm}$ to $2 \mathrm{~cm}$ in width. Sometimes they broaden into plaques, especially on the buttocks. The lesion may be only a few centimetres in length, but may extend the entire length of the limb. Almost any skin site may be affected, including the face (3). However, a common presentation is a progressively lengthening collection of erythematous 
papules starting on the proximal portion of the upper or lower extremity, progressing over several months to acral skin, commonly a digit, even extending down a limb to the nails. The abdomen, buttocks and thighs may be involved by unilateral extensive lesions. Generally, multiple lesions are rare, bilateral involvement is exceptional, but parallel linear bands or zosteriform patterns have been reported (1). No associated systemic abnormalities have been identified (1). While some of the skin lesions are asymptomatic, others may be quite pruritic (5).

Histological presentation of lichenoid dermatitis with patchy or band like lymphocytic interface dermatitis similar to lichen planus may occur, but presence of psoriasiform epidermal hyperplasia, inflammatory infiltrate of lymphocytes, melanophages and histiocytes in the papillary dermis, especially in the deeper perifollicular layer is believed to be a relatively characteristic finding $(2,4)$.

Just as rapidly as LS starts, it resolves, leaving variable dyspigmentation (4). In most cases spontaneous resolution can be expected within 3-6 months, but some lesions may persist for over a year. There is no standard treatment for LS, apart from observation, and it should be given for cosmetic or psychological reasons only (1).

Here we present a case of lichen striatus in an adult female with Blaschko linear acquired inflammatory skin eruption successfully treated with cryotherapy.

\section{Case Report}

\section{History}

A 27-year-old, otherwise healthy flight attendant was referred to our Outpatient Department with an erythematous, linear, slightly itchy eruption on the left leg. The lesion developed suddenly, three months after delivery, rapidly progressing over the first week involving the entire length of the limb, and subsequently became stable. The eruption was not preceded by a sore throat, recent infection, sick contacts or constitutional symptoms. There was no history of drug use or any topical application. The patient's medical history was unremarkable, but her family history was positive, as her mother suffered from allergic rhinitis.

\section{Dermatologic examination}

The physical examination of the flexor aspect of the lower left limb showed small pink, coalescing scaly papules without umbilication or Wickham's striae, with a linear distribution following one BL down to the ankle, with a band broadening into plaque on the left buttock; the surface of the lesion was rough, slightly hyperkeratotic and scaly (Figures 1,2). Apart from generalized xerosis, there was no other sign of atopic dermatitis.

\section{Laboratory tests}

Laboratory tests results were within normal limits, except the total $\operatorname{IgE}$ serum levels: significantly increased $700 \mathrm{IU} / \mathrm{ml}$ (reference value $\leq 100 \mathrm{IU} / \mathrm{ml}$ ).

\section{Histopathological findings}

Histological analysis of skin lesion revealed: slightly hyperkeratoticepidermis, with rather deep invagination filled with keratin and vacuolar alteration of the basal layer showing very few necrotic keratinocytes; papillary dermis with a band-like infiltrate of lymphocytes admixed with some histiocytes and melanophages; the infiltrate extended into the basal layer of the epidermis, and perifollicularly into the deeper dermal region (Figures 3 and 4).

Based on patient's history, clinical examination and pathohistological analysis, the diagnosis of LS was made.

\section{Therapy}

First, a topical corticosteroid cream (mometasone furoate $0.1 \%$ ) was applied twice daily for 2 weeks, primarily for esthetical reasons. Besides relieving the itching, the therapy showed to be ineffective in reducing the linear lesions. For this reason, sequential cryotherapy was performed in two freezing cycles, using a Cry-Ac ${ }^{\ominus}$ device (Brymill Cryogenic Systems, Brimill company, Ellington, USA). Liquid nitrogen was applied to the linear lesions for 30 seconds, and a 2-mm white halo formed. Cryotherapy was performed twice, with a 2 week interval, whereas the treated surface was treated with an antibiotic cream (Gentamicin) (Figure 5). Apart from common post-therapeutic reactions including mild burning sensation, erythema and development of small blisters 48 hours after cryotherapy, there were no other complications. 


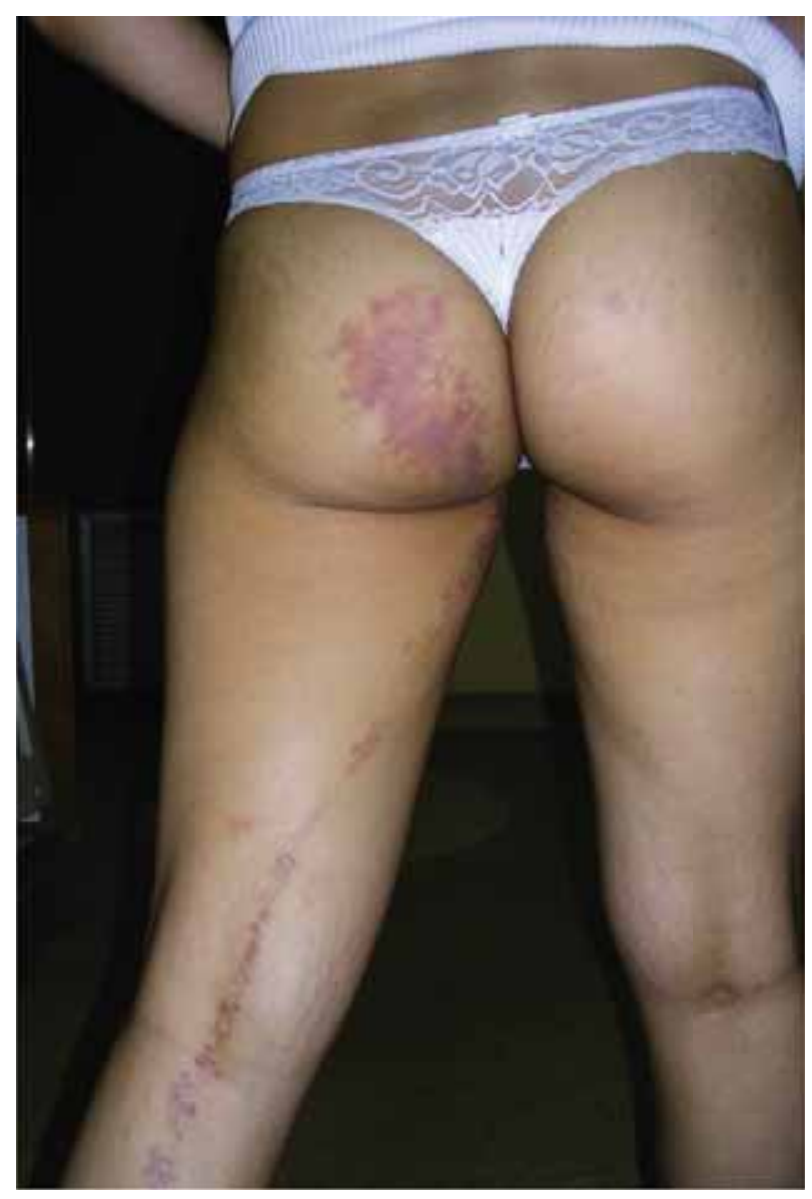

Figure 1. Clinical presentation before therapy: pink, coalescing scaly papules linearly distibuted following one BL down the left lower limb, with band broadening into plaque on the left buttock

Complete regression of the treated lesions was achieved twelve weeks after the last treatment. In the final phase of therapy, topical Contractubex ${ }^{\odot}$ cream $^{2}$ was indicated twice a day for a month (Figure 6). A systemic antihistamine (Desloratadine) was used to relieve itching.

\section{Discussion}

LS mostly shows a great confinement to Blaschko lines (BL) which are a manifestation of cutaneous mosaicism, a postzygotic genomic alteration, specifically a somatic mutation in which different groups of skin cells behave differently for unknown reasons; $\mathrm{BL}$ are believed to reflect the embryologic migration of these aberrant skin cells (1). Moreover, another theory proposing "epigenetic mosaicism" with transposable elements or retrotransposons has recently emerged: it has actually been hypothesized that these elements which are present in a large portion of the human genome, can activate or inactivate (via methylation or demethylation) the neighboring genes (6). A recent report on the unique simultaneous occurrence of LS in two related siblings (one suffering from recurrent otitis media) along the same BL, supports the infectious and genetic components in the development of LS (7). This report also supports the latter theory of epigenetic mosaicism, since this theory is based strictly on familial occurrence of LS, in contrast to the former, which supports somatic mutations with occurrence by chance, when familial incidence is improbable (7). Although familial occurrences are extremely rare, it seems most likely that different endogenous or exogenous factors may lead to the unmasking of tolerance to an abnormal keratinocyte clone in apparently healthy,

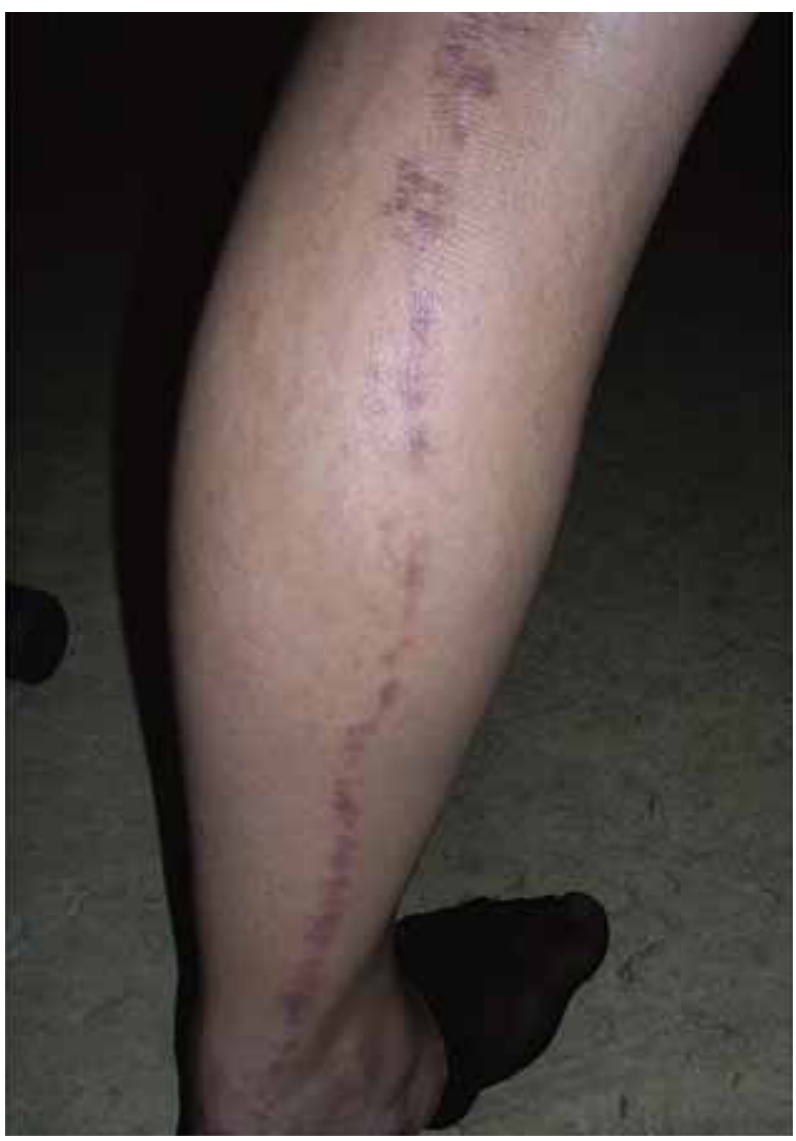

Figure 2. Clinical presentation before therapy: pink, coalescing scaly papules linearly distibuted following one BL down the lower limb to the ankle 


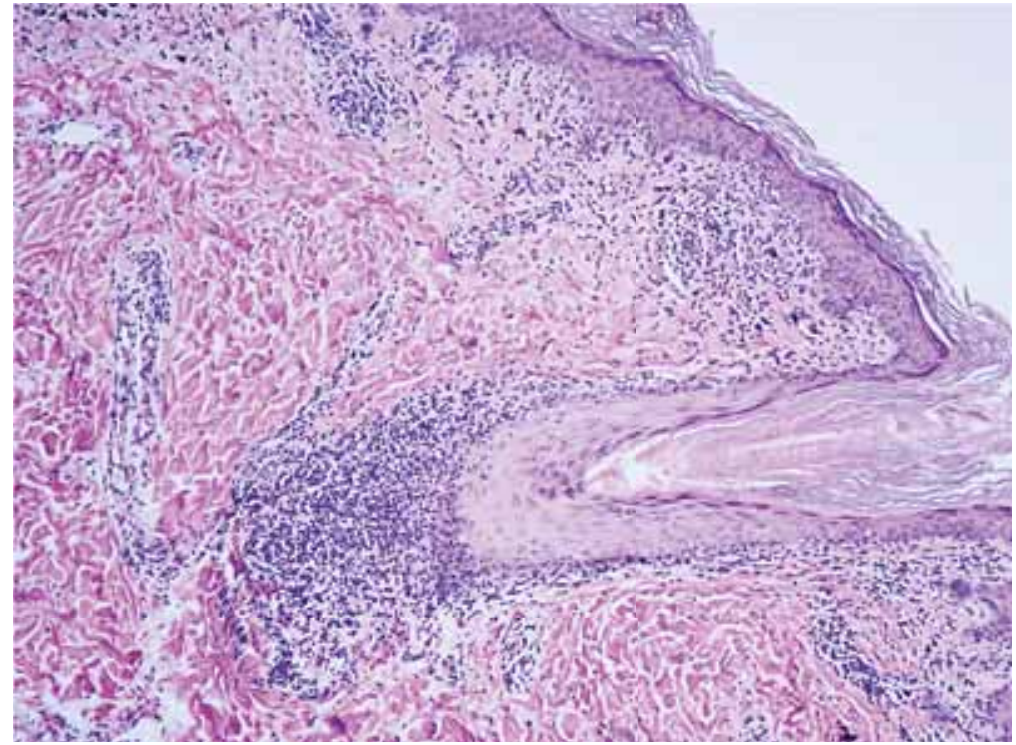

Figure 3. Histological analysis of the skin lesion revealed: the epidermis slightly hyperkeratotic, with rather deep invagination filled with keratin and vacuolar alteration of the basal layer showing very few necrotic keratinocytes; papillary dermis with a band-like infiltrate of lymphocytes admixed with some histiocytes and melanophages; the infiltrate spread into the deeper part of the epidermis, as well as perifollicular region (hematoxylin and eosin, $\mathrm{x} 40$ )

but genetically predisposed individuals. Based on current evidence, the endogenous triggering event in unmasking these clones is likely to be an aberrant cell-mediated immunologic mechanism. Thus, Racette et al., hypothesize that individuals with
LS are predisposed with partially silenced genomic transposable elements which are methylated or demethylated by an immunologic reaction to an infection. The infection acts only as an initiator of the aberrant cell-mediated immune response by creating

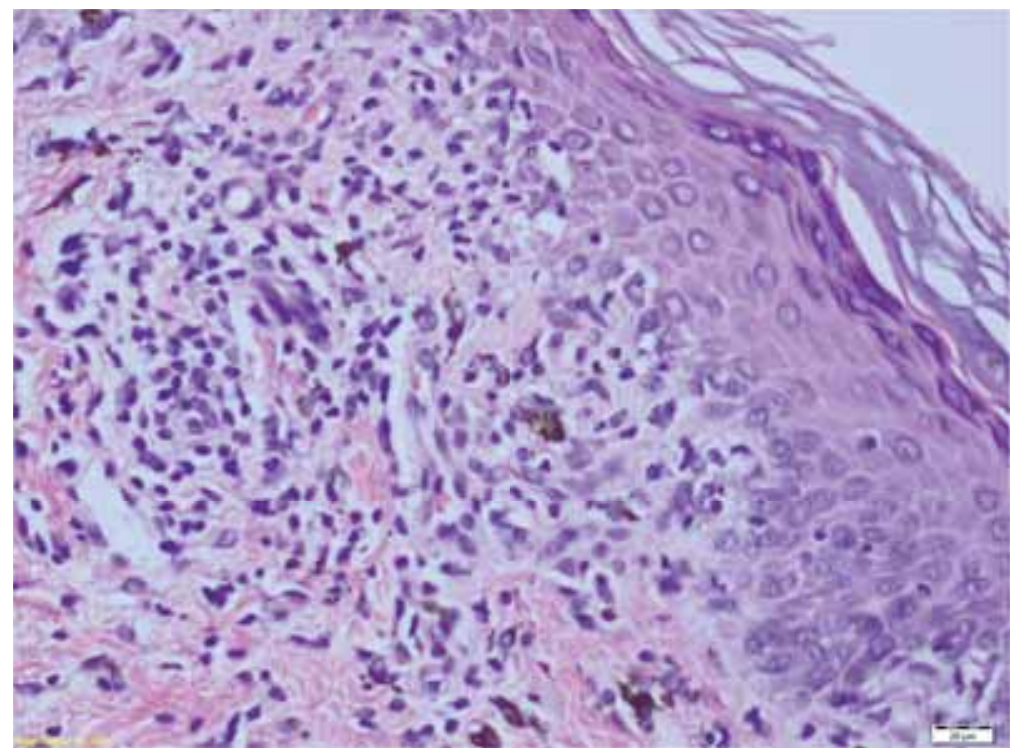

Figure 4. Higher magnification reveals: vacuolar degeneration of basal keratinocytes; chronic inflammatory infiltrate spreading from papillary dermis into the deeper part of epidermis; pigmented melanophages in the infiltrate (hematoxylin and eosin, $\mathrm{x} 200$ ) 


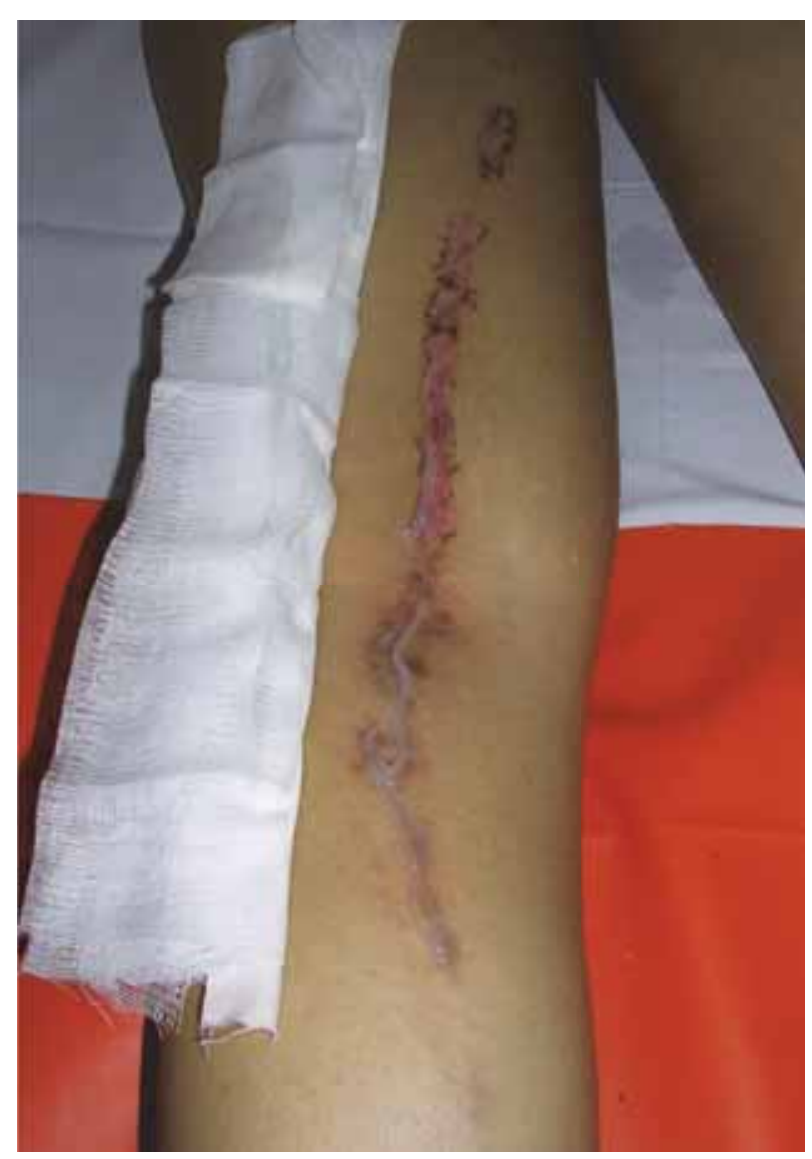

Figure 5. Clinical presentation two weeks after initiation of cryotherapy

a cellular alteration (7). Recently reported association of LS with Blaschkoid pityriasis rosea in the same location, also supports this concept (8). Moreover, the lack of viral particles in the lesions reported by some authors substantiates the hypothesis that infection or other exogenous triggers (e.g., environmental agents, cutaneous injury and hypersensitivity reaction) need only to initiate the cell-mediated immune response. The absence of prodromal symptoms in our patient as in most cases, does not exclude the possibility of asymptomatic illness triggering LS (7).

The occurrence of LS after allogenic stem cell transplantation was hypothesized to be an unusual form of localized, chronic graft-versus-host disease (9). This occurrence provided further support for the immunohistochemistry findings of necrotic keratinocytes bordered by CD8+T cells in LS (10), acting as cytotoxic lymphocytes eradicating mutant cells as probable target in LS.
Regarding aberrant cell-mediated immune mechanism acting as an endogenous triggering event in unmasking aberrant clones, this hypothesis could be substantiated by the higher association of atopy with LS reported by some authors (11). However, Taniguchi et all., have found an association between LS and personal history of atopy, which closely approaches the incidence of atopy in the general population (12). Thus, the association of LS with a positive personal or family history of atopy, like in our patient, is still unclear. The occurrence of LS three months after delivery reported here is also unclear, since it cannot be supported by similar literature data.

In our patient, the diagnosis of LS was made based on the: history of sudden development and rapid linear spread of lesions; clinical presentation of small pink, coalescing scaly papules without umbilication or Wickham's striae, with a linear distibution following

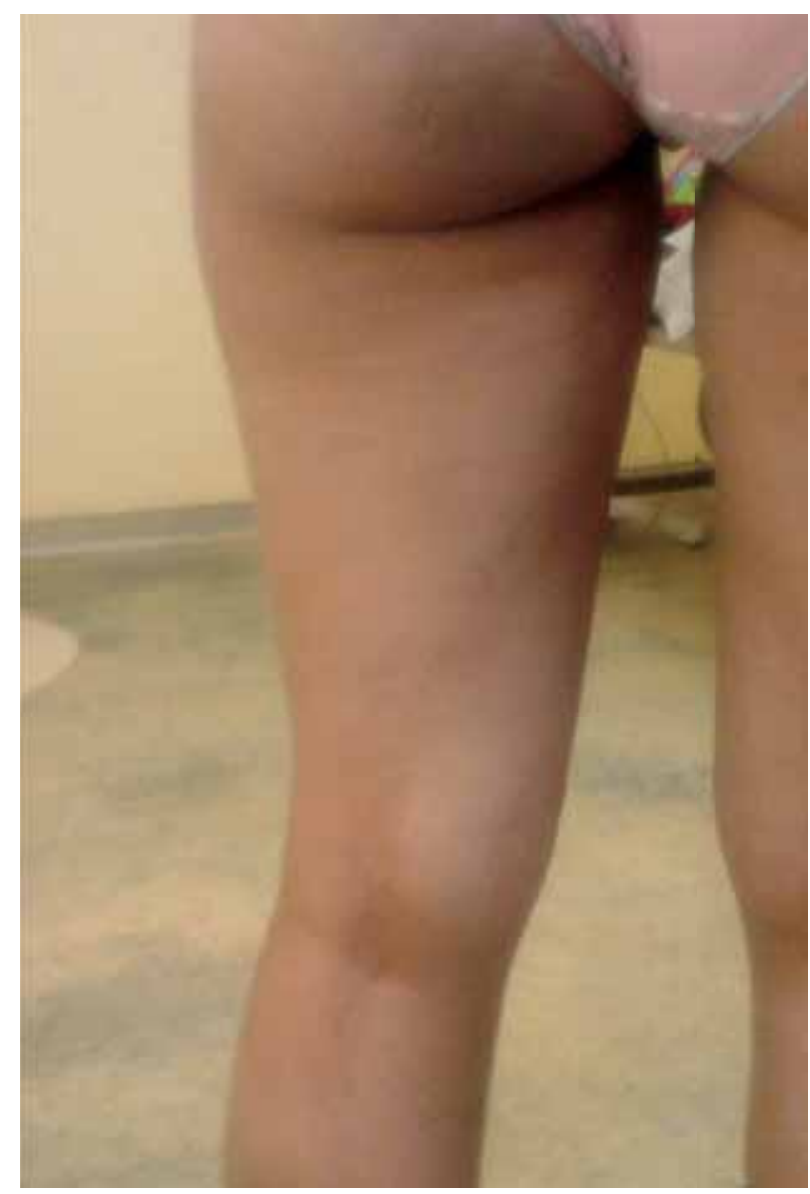

Figure 6. Clinical presentation twelve weeks after treatment 
one BL down a lower limb to the ankle, with band broadening into plaque on the left buttock; histology showed some hyperkeratosis, lichenoid dermatitis similar to lichen planus, but with the presence of inflammatory infiltrate of lymphocytes admixed with some histiocytes and melanophages located in the papillary dermis as well as deeper in the perifollicular arrangement.

Several generalized dermatoses either occasionally follow BL, probably reflecting a clonal "susceptibility mutation" (linear lichen planus, porokeratosis, linear lichen nitidus, lichen striatus (eczema), segmental vitiligo, linear morphea nevoid psoriasis, Darier's disease, Hailey-Hailey disease, "adult Blaschkitis" - BLAISE (acronym for Blaschko linear acquired inflammatory skin eruption), or have also been reported in a linear or nevoid distribution (lupus erythematosus fixed drug eruption, chronic graft-versus-host disease and mycosis fungoides) (13). Probably, they all reflect genetic mosaicism, the former for multifactorial dermatoses with an autosomal dominant component, and the latter for potentially lethal dominant mutations rescued by mosaicism (13). They can can also be differed from inflammatory linear verrucous epidermal nevus (ILVEN) and child nevus, which occur at or soon after birth and usually persist lifelong, However, LS is considered to have a greater affinity to BL than any other condition. Some authors propose "adult Blaschkitis" a remitting and relapsing eruption of itchy inflammatory vesicles and papules occurring usually on the trunk in adults and adult version of LS to be the same entity $(14,15)$, while the others think BLAISE should perhaps be considered a description rather than a diagnosis (13).

Although LS has variable histologic presentations, histological analysis may be helpful. LS most closely resembles linear lichen planus and inflammatory linear verrucous epidermal nevus (ILVEN). Linear lichen planus and LS display the same histopathology as classical lichen planus, but LS may also show superficial or deep perivascular and/or periadnexal (perifollicular in our patient), localization of the infiltrate. The epidermal changes in ILVEN usually more closely resemble psoriasis than interface dermatitis, while the significant acanthosis and hyperkeratosis in verrucous ILVEN are absent in LS (4). The histology of "adult Blaschkitis" shows remitting and relapsing eruption of itchy inflammatory vesicles and papules most frequently localized on the trunk in adults, and it is more eczematous (spongiotic) than lichenoid. Lichen nitidus exhibits more histiocytic than lymphocytic lichenoid interface dermatitis with epidermis showing atrophy and parakeratosis (2). Perifollicular infiltrate in lupus erythematosus exhibits denser perifollicular lymphocytes and increased interstitial mucin deposits (2).

Standard treatment for LS is usually only observation, because of its benign, self limited course, and should be given for cosmetic or psychological reasons only (1). Not only rapid resolution of skin lesions but also complete resolution of pruritus was sustained in one series by combining a topical retinoid with a topical steroid (5). In order to achieve satisfying cosmesis in our patient responding her occupational demands, she was successfully treated with cryotherapy, which she tolerated well without any side effects.

\section{Conclusion}

Here we present a case of lichen striatus in an adult female as a Blaschko linear acquired inflammatory skin eruption successfully treated with cryotherapy. According to world literature available to us, this is the first report of successful treatment of LS with this therapeutic option.

\section{Abbreviations}

\author{
LS - lichen striatus \\ $\mathrm{BL}$ - Blaschko lines \\ BLAISE - Blaschko linear acquired inflammatory \\ skin eruption
}

\section{References}

1. Berth-Jones J. Eczema, lichenification, prurigo and erythroderma. In: Burns T, Breathnach S, Cox N, Griffiths C, editors. Rook's textbook of dermatology. 8th ed. Oxford: Blackwell Publishing; 2010. p. 23.1-23.51.

2. Fung MA. Inflammatory diseases of the dermis and epidermis. In: Busam KJ, editor. Dermatopathology. Philadelphia: Saunders, Elsevier; 2016. p. 11-78.

3. $\mathrm{Mu}$ EW, Abuav R, Cohen BA. Facial lichen striatus in children: retracing the lines of Blaschko. Pediatr Dermatol 2013;30(3):364-6.

4. Ramos Ceballos FI, Horn TD. Interface dermatitis In: Barnhill RL, Crowson AN, Magro CM, Piepkorn MW, editors. Dermatopathology. $3^{\text {rd }}$ ed. New York: The McGraw-Hill Companies; 2010. p. 36-63.

5. Youssef SM, Teng JM. Effective topical combination therapy 
for treatment of lichen striatus in children: a case series and review. J Drugs Dermatol 2012;11(7):872-5.

6. Happle R. Transposable elements and the lines of Blaschko: a new perspective. Dermatology 2002;204(1):4-7.

7. Racette AJ, Adams AD, Kessler SE. Simultaneous lichen striatus in siblings along the same Blaschko line. Pediatr Dermatol 2009;26(1):50-4

8. Verma P, Singal A, Yadav P, Sharma R. Concurrence of lichen striatus and localised pityriasis rosea: cutaneous mosaicism. Australas J Dermatol 2013;54(1):41-2.

9. Mun JH, Park HJ, Kim HS, Kim SH, Ko HC, Kim BS. Lichen striatus occurring after allogenic peripheral blood stem cell transplantation in an adult with aplastic anemia. Ann Dermatol 2012;24(1):87-9.

10. Zhang Y, McNutt NS. Lichen striatus: histological, immunohistochemical, and ultrastructural study of 37 cases. J Cutan
Pathol 2001;28(2):65-71.

11. Patrizi A, Neri I, Fiorentini C, Bonci A, Ricci G. Lichen striatus: clinical and laboratory features of 115 children. Pediatr Dermatol 2004;21(3):197-204.

12. Taniguchi Abagge K, Parolin Marinoni L, Giraldi S, Carvalho VO, de Oliveira Santini C, Favre H. Lichen striatus: description of 89 cases in children. Pediatr Dermatol 2004;21(4):440-3.

13. Moss C. Shahidullah H. Naevi and other developmental defects. In: Burns T, Breathnach S, Cox N, Griffiths C, editors. Rook's textbook of dermatology. 8th ed. Oxford: Blackwell Publishing; 2010. p. 18.1-18.107.

14. Hofer T. Lichen striatus in adults or 'adult blaschkitis'? There is no need for a new naming. Dermatology 2003;207(1):89-92.

15. Mueller CS, Schmaltz R, Vogt T, Pfohler C. Lichen striatus and blaschkitis: reappraisal of the concept of blaschkolinear dermatoses. Br J Dermatol 2011;164(2):257-62.

\section{Lichen striatus kod odrasle osobe lečene krioterapijom - prikaz slučaja}

\section{Sažetak}

Uvod. Lichen striatus (sinonim - linearna lihenoidna dermatoza, LS) predstavlja linearnu inflamatornu dermatozu nepoznate etiologije. U najvećem broju slučajeva promene u LS se lokalizuju duž Blaškovih linija (engl. Blaschko lines, BL), ali faktori koji su odgovorni za linearni raspored lezija nisu dovoljno razjašnjeni. Oboljenje se javlja godinu dana nakon rođenja, najčešće kod dece uzrasta 5-15 godina. Javlja se i kod odraslih osoba u vidu linearne promene koja nastaje konfluencijom malih eritematoznih promena ili nepromenje boje kože papula koje nisu umbilikovane i na svojoj površini nemaju Vikamove (Wickham) strije ali mogu pokazivati laku deskvamaciju. Za LS je karakterističan iznenadni početak i brzo progresivno širenje tako da vrlo brzo promena u celini poprima linearni $2 \mathrm{~mm}$ do $2 \mathrm{~cm}$ širok trakasti izgled, neravnu površinu i različitu dužinu, od nekoliko centimetara pa do dužine celog ekstremiteta uz zahvatanje nokta. Oboljenje se može javiti na skoro svim delovima tela uključujući i lice. Multiple lezije su retke, bilateralno zahvatanje je izuzetno retko, ali su objavljeni slučajevi sa paralelnim linearnim trakastim ili zosteriformnim rasporedom; ne javlja se udruženo sa sistemskim poremećajima. Oboljenje u najvećem broju slučajeva protiče asimptomatski ali pruritus može biti u pojedinim slučajevima intenzivan.
Histološki, za LS su karakteristični znaci lihenoidnog dermatitisa ali se u pojedinim slučajevima u histološkoj analizi mogu detektovati promene za koje se pretpostavlja da su karakteristične za LS: psoriaziformna epidermalna hiperplazija, inflamatorni infiltrat $u$ papilarnom dermisu, u kome se pored limfocita nalaze histiociti i melanofagi, perivaskularno i periadneksalno širenje infiltrata. Spontana rezolucija promena se može očekivati u periodu od 3 do 6 meseci, ali i duže.

Standardna terapija podrazumeva samo praćenje, u slučaju jačeg svraba ili, iz kozmetičkih i psiholoških razloga, mogu se u terapiju uključiti topikalni kortikosteroidi ili kalcineurinski inhibitori - takrolimus ili pimekrolimus.

Prikaz slučaja. Dvadesetsedmogodišnja ženska osoba, inače dobrog zdravstvenog stanja, po zanimanju stjuardesa, upućena je na pregled dermatologu zbog pojave eritematozne linearne promene na levoj nozi, koja je naglo nastala tri meseca posle porođaja, progredila veoma brzo da bi u roku od nedelju dana zahvatila dužinu cele noge i bila praćena osećajem slabog svraba. Promeni nije prethodila infekcija gornjih respiratornih puteva niti bilo koji drugi poremećaj, uzimanje lekova niti lokalna aplikacija bilo kakavih preparata. Lična anamneza za atopiju je bila negativna ali je njena majka bolovala i lečila se od alergijskog rinitisa. 
Prilikom pregleda, na koži leve noge uočeno je prisustvo unilateralne, solitarne linearne oko $0,5-0,8$ $\mathrm{cm}$ široke trakaste promene, neravne, orožale površine, nastale aglomeracijom sitnih, ružičastosmeđih papula, dijametra nekoliko milematara, na čijoj površini nije bilo Vikamovih figura već umerene deskvamacije. Promena je bila neravne, umereno orožale i deskvamirane površine, pratila je jednu BL i od plaka, veličine dlana ženske osobe, lokalizovanog na levom gluteusu, protezala se duž čitave fleksorne strane leve noge do unutrašnjeg maleolusa (slike 1 i 2). Osim kseroze, na koži nije bilo drugih promena niti znakova koji bi ukazivali na prisustvo atopijskog dermatitisa.

Od laboratorijskih analiza jedino je utvrđen povišen nivo imunoglobulina klase E koji je iznosio $700 \mathrm{IU} / \mathrm{ml}$ (referalna vrednost $\leq 100 \mathrm{IU} / \mathrm{ml}$ ).

Histološka analiza isečka ledirane kože pokazala je sledeće: slabo izražena hiperkeratoza epidermisa sa vakuolnom degeneracijom i malim brojem nekrotičnih keratinocita u bazalnom sloju; linearni trakasti infiltrat u papilarnom dermisu sastavljen od limfocita, pigmentofaga i manjeg broja histiocita; inflitrat je pokazivao epidermalnu egzocitozu i perifolikulano nakupljanje (slike 3 i 4).

$\mathrm{Na}$ osnovu anamneze, kliničkog pregleda i patohistološke analize, postavljena je dijagnoza LS. Prvenstveno iz estetskih razloga, ordiniran je prvo lokalno kortikosteroidni krem (mometazon fuorat $0,1 \%)$ dvaput dnevno tokom dve nedelje. Ova terapija nije dala rezultat u smislu smanjenja ili regresije linearne promene - samo je ublažila svrab. Iz ovih razloga je preduzeta sekvencijalna krioterapija koja je sprovedena u duplom ciklusu zamrzavanja (double cycling freezeng). Korišćen je aparat Cry-Ac ${ }^{\oplus}$ (Brymill Cryogenic Systems, Brimill company, Ellington, USA). Tečni azot je nanošen na linearnu promenu u trajanju od 30 sekundi sa stvaranjem oko lezije haloa debljine $2 \mathrm{~mm}$. Krioterapija je izvođena u dva navrata sa periodom oporavka između dva tretmana u trajanju od dve nedelje i tada je na tretirane površine aplikovan antibiotski krem (gentamicin) (Slika 5). Osim osećaja slabog pečenja i uobičajene postterapijske reakcije u vidu eritema i manjih plikova nastalih 48 časova posle kriotretmana, nije bilo drugih tegoba. Kompletna regresija tretiranih promena nastupila je dvanaest nedelja nakon poslednjeg tretmana. U završnoj fazi na tretiranu površinu je lokalno aplikovan Contractubex ${ }^{\oplus}$ krem dvaput dnevno tokom mesec dana (Slika 6). Osećaj svraba kupiran je sistemskom primenom antihistaminika (desloratadin).

Diskusija. Distribucija promena LS pokazuje veliki afinitet prema BL, koje predstavljaju izraz kutanog mozaicizma kod ljudi, postzigomatski genomski proces koji se verovatno odvija u obliku somatske mutacije u različitim ćelijama kože i čini da se ove ćelije ponašaju neuobičajeno iz za sada nepoznatih razloga. Pretpostavlja se da BL odražavaju put kojim ove aberantne ćelije migriraju za vreme embrionalnog perioda. Druga teorija promoviše epigenetski mozaicizam koji podrazumeva ulogu transpozomnih elemenata tzv. retrotranspozona za koje je utvrđeno da zauzimaju veliki deo genoma ljudske vrste. Ova teorija se zasniva na hipotezi da ovi elementi putem metilacije/demetilacije, izazivaju aktivaciju, odnosno inaktivaciju susednih gena. U prilog ovoj teoriji priključuje se i nedavno objavljena istovremena pojava LS duž iste BL kod dva rođena brata (kod jednog od braće pojavi LS prethodio je otitis medija), koja je podržala ulogu genetskih faktora i infekcije u nastanku LS. Štaviše, ovim je podržana i torija o epigenetskom mozaicizamu, s obzirom da se njome može objasniti familijarna pojava oboljenja, za razliku od somatskih mutacija koje se dešavaju slučajno, kada bi familijarna pojava oboljenja bila malo verovatna. Iako je porodična pojava oboljenja ekstremno retka (porodična anamneza kod naše pacijentkinje negativna) najverovatnije da $u$ nastanku LS različiti endogeni ili egzogeni faktori mogu izazvati demaskiranje navedenih abnormalnih klonova keratinocita kod inače zdravih ali genetski predisponiranih osoba. Epigenetski mozaicizam promoviše hipotezu da se genetska predispozicija zasniva na metilaciji/demetilaciji retrotranspozona, koju izaziva imunska reakcija pokrenuta infekcijom. Pretpostavlja se da infekcija inicira aberantni ćelijski imunski odgovor, pošto izazove ćelijsku (keratinociti kože) aberaciju. Nedavno objavljena istovremena pojava unilateralno lokalizovane blaškoidne pitiriazis rozee (Pityriasis rosea) sa istostranim LS potkrepljuje ovu hipotezu da infekcija i/ili drugi egzogeni okidači (npr. spoljašnji činioci, trauma ili alergijske reakcije) iniciraju imunski odgovor, što istovremeno objašnjava zašto pojedini autori u lezijama LS nisu detektovali infektivne uzročnike (virusne partikule). Odsustvo prodromalnih simptoma kod naše pacijentkinje 
kao i u većini slučajeva, ne isključuje mogućnost asimptomatske infekcije.

$\mathrm{Na}$ aberantni imunski odgovor ukazuje i signifikantna udruženost atopije sa LS koju su objavili pojedini autori. Značaj udruženosti LS sa pozitivnom ličnom ili porodičnom anamnezom o atopiji kao što je slučaj kod naše pacijentkinje, ostaje nedovoljno razjašnjen, $s$ obzirom da su rezultati drugih autora ukazali da prevalencija atopije (anamnezni podaci) u LS ne odstupa od one u opštoj populaciji. Takođe pojava LS tri meseca nakon porođaja kod naše pacijentkinje zahteva potvrdu u radovima drugih autora.

Dijagnoza LS je kod naše pacijentkinje postavljena na osnovu sledećeg: anamneze o iznenadnoj pojavi i brzom širenju (tokom jedne nedelje) linearne promene; klinički izgled promene nastale aglomeracijom malih ružičastosmeđih papula na čijoj površini nisu bile prisutne Vikamove figure, već skvame, koja se sa lako hiperkeratotičnom i neravnom površinom linearno pružala u vidu trake od plaka na levom gluteusu do levog unutrašnjeg maleolusa, duž cele fleksorne strane leve noge; prisustvo hiperkeratoze i lihenoidnog dermatitisa u epidermisu i papilarnom dermisu ledirane kože, što je nalaz sličan sa nalazom za lihen planus, ali se za razliku od njega u infiltratu pored limfocita nalaze melanofagi i histiociti a infiltrat se širi dublje i lokalizuje i perifolikularno.

U diferencijalnoj dijagnozi na prvom mestu treba isključiti linearni lihen planus i inflamacijski linearni verukozni epidermalni nevus (engl. inflammatory linear verrucous naevus - ILVEN). Iako LS može imati različitu histološku prezentaciju koja se u pojedinim slučajevima ne može razlikovati od prezentacije karakteristične za lihen planus, ono što ih može razlikovati i što se smatra najkarakterističnijim histološkim nalazom lihen strijatusa jeste prisustvo infiltrata ne samo u površnim delovima dermisa nego i njegova lokalizacija periadneksalno, tj. perikrino ili perifolikularno kao kod naše pacijentkinje. Epidermalne promene u ILVEN u najvećem broju slučajeva podsećaju na one karakteristične za psorijazu, dok su znaci lihenoidnog dermatitisa odsutni. Lihen nitidus u infiltratu ima dominaciju histiocita a u epidermisu atrofiju i parakeratozu. Perifolikularni infiltrat karakterističan za lupus eritematozus, pored perifolikularnih limfocitnih infiltrata, sadrži u intersticijumu depozite mucina.

Zaključak. U ovom radu prikazan je slučaj odrasle ženske osobe kod koje je lihen strijatus, koji se pojavio naglo, tri meseca nakon porođaja, uspešno lečen krioterapijom. Prema nama dostupnoj literaturi, ovo bi bio prvi objavljen slučaj uspešnog lečenja ovim vidom terapije.

Ključne reči: Lichen sclerosus et atrophicus; Lihenoidne erupcije; Odrasli; Krioterapija; Ishod terapije; Prikazi slučajeva 